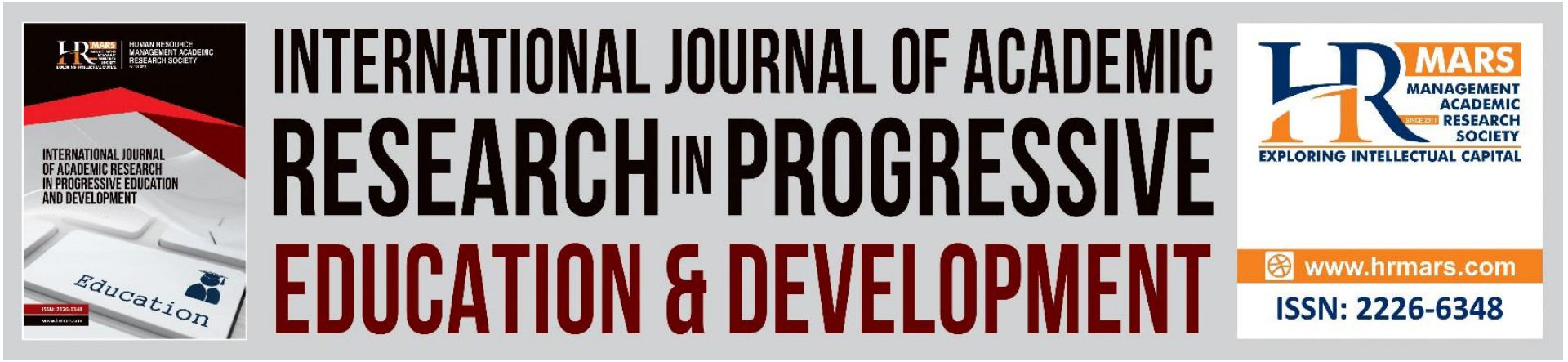

\title{
Teachers' Knowledge, Skills, and Readiness in the Guidance of Self-Advocacy Skills to Students with Special Needs
}

\author{
Norzaliana Mat Nuri, Manisah Mohd Ali \& Norshidah Mohammad Salleh
}

To Link this Article: http://dx.doi.org/10.6007/IJARPED/v10-i3/11083

DOI:10.6007/IJARPED/v10-i3/11083

Received: 01 June 2021, Revised: 05 July 2021, Accepted: 25 July 2021

Published Online: 18 August 2021

In-Text Citation: (Nuri et al., 2021)

To Cite this Article: Nuri, N. M., Ali, M. M., \& Salleh, N. M. (2021). Teachers' Knowledge, Skills, and Readiness in the Guidance of Self-Advocacy Skills to Students with Special Needs. International Journal of Academic Research in Progressive Education and Development, 10(3), 563-578.

Copyright: (C) 2021 The Author(s)

Published by Human Resource Management Academic Research Society (www.hrmars.com)

This article is published under the Creative Commons Attribution (CC BY 4.0) license. Anyone may reproduce, distribute, translate and create derivative works of this article (for both commercial and non-commercial purposes), subject to full attribution to the original publication and authors. The full terms of this license may be seen at: http://creativecommons.org/licences/by/4.0/legalcode

Vol. 10(3) 2021, Pg. 563 - 578

http://hrmars.com/index.php/pages/detail/IJARPED

JOURNAL HOMEPAGE

Full Terms \& Conditions of access and use can be found at http://hrmars.com/index.php/pages/detail/publication-ethics 


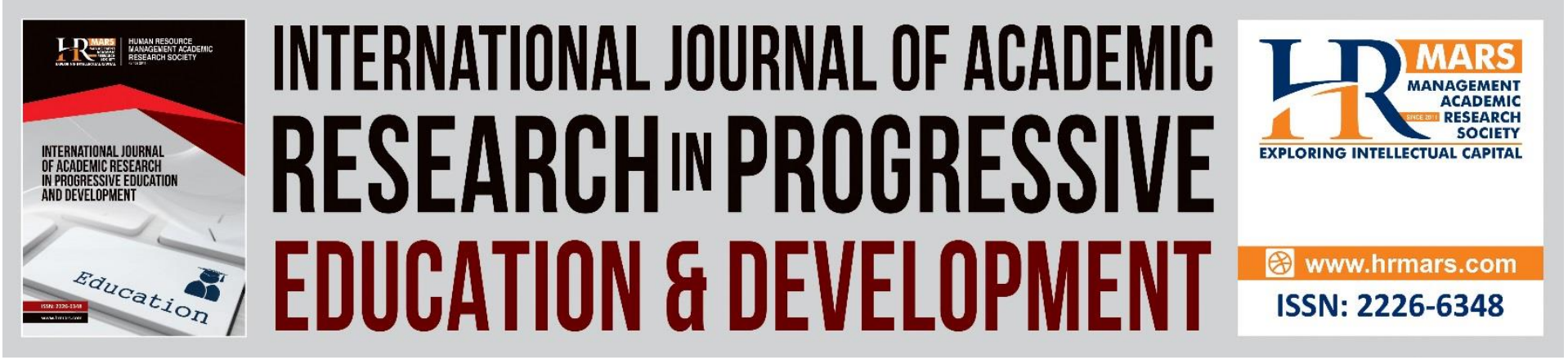

\title{
Teachers' Knowledge, Skills, and Readiness in the Guidance of Self-Advocacy Skills to Students with Special Needs
}

\author{
Norzaliana Mat Nuri, Manisah Mohd Ali \& Norshidah \\ Mohammad Salleh \\ National University of Malaysia, Malaysia
}

\begin{abstract}
Self-advocacy skills are important skills that must be possessed by all individuals, including students with special needs. However, these skills have to be guided by important people, such as teachers for students with special needs. This case study used a fully qualitative approach in obtaining the study data. The purpose of this study was to explore the knowledge, skills, and readiness of teachers in guiding self-advocacy skills to students with special needs. The study data were obtained from semi-structured interviews using an interview protocol on fifteen participants consisting of ten special education teachers and five guidance and counselling teachers. Framework editing from Miles and Huberman was executed to analyze the data. The data was given codes or themes predetermined before the in-depth data analysis. The study results revealed that participants have a lack of knowledge regarding selfadvocacy skills. Most participants were also less prepared to teach or guide these skills to students with special needs. However, they are willing to teach with proper training and exposure to self-advocacy skills. This study implies for the development of training modules on teaching self-advocacy skills for teachers. The training modules would help them to enhance their knowledge, skills, and readiness to teach more effective self-advocacy skills to students with special needs.
\end{abstract}

Keywords: Self-advocacy Skills, Knowledge, Skills, Readiness, Students with Special Needs

\section{Introduction}

Teachers are the closest individuals to students. Therefore, they also play a role in bringing changes to students in the school. According to Nor and Rashed (2018), teachers need to become 'true', which is the essence of the teaching profession to promote the successful development of students' personalities and achieve students' aspirations in the school. Therefore, teachers need to have the skills, knowledge, commitment, awareness, and motivation in providing students with the necessary skills (Nor \& Rashed, 2018). Nevertheless, not all teachers have the skills and knowledge to teach self-advocacy skills to students with special needs. This statement was mentioned in studies by Lan (2007; 2010); Betinez, Morningstar and Frey (2009) that secondary school teachers lacked the knowledge and skills to teach self-advocacy skills to students with special needs. 
Teachers' knowledge and skills are important aspects that need to be constantly enhanced to provide appropriate education and guidance. Knowledge and skills are the defining factors of a teacher's efficiency and competence. According to He, Lundgren, and Pynes (2017), a competent teacher performs a task with full discipline and willingly. Teachers who have the knowledge and skills can teach and guide students according to their abilities, especially students with special needs (Leko et al., 2015; Mazzotti et al., 2018; Ok, Hughes \& Boklage, 2017). According to Salleh, Alias, and Jelas (2009), teachers with a high level of knowledge and skills can help students with special needs, especially with their learning difficulties during the teaching and learning process in the school. Indirectly, this approach will affect students' excellence and social development. Lamont et al (2018) found that teachers who use different teaching styles according to the needs and abilities of students with special needs can establish a good relationship with them. However, Lan (2007); Betinez et al (2009) found that secondary school teachers lacked the knowledge and skills to teach self-advocacy skills to students with special needs. As a result, they were less prepared to teach these skills to students with special needs during the transition, starting from school years leading up to the post-secondary school setting (Lan, 2007). This situation was due to not receiving training and exposure on the importance of self-advocacy skills for students with special needs from the very beginning (Michale \& Zidan, 2018; Yeo, 2007). Teachers are still looking for the best method to teach self-advocacy skills to students with special needs because they did not have any reference materials or clear guidelines.

Teachers' readiness in teaching is an important aspect apart from their knowledge and skills. According to Rashid (2016), teachers' readiness in transferring knowledge to students is vital in ensuring the success of their students. Similarly, Jusoh (2012) stated that the effectiveness of teaching students with special needs is fully dependent on teachers' readiness, especially in terms of attitude and knowledge level in using teaching strategies and approaches suitable to students' needs. Teachers' readiness to guide self-advocacy skills is important to ensure that the teaching and guidance to students with special needs are effective. Besides that, Chabra, Srivistava and Srivistava (2010) found that mainstream class teachers were not ready and afraid of students with special needs that they would often react negatively. Jaladin (2013) revealed that counsellors experienced fear and anxiety when dealing with students with special needs. Hence, teachers' readiness is important in guiding students with special needs. Teachers should be given specific training or courses to improve their knowledge, skills, and readiness to teach self-advocacy skills to students with special needs (Zamri \& Hanifah, 2015; Derapa \& Mohamed, 2019).

The role of teaching and guiding self-advocacy skills to students with special needs is not solely placed on special education teachers. It has to be shared with other teachers, especially the guidance and counselling teachers. Guidance and counselling teachers are qualified to guide self-advocacy skills to students with special needs as they are trained to incorporate mentoring skills. The combination of expertise between guidance and counselling teachers and special education teachers is necessary for guiding students with special needs (Azman et al., 2019; Landmark, Ju \& Zhang 2010; Zhang, Invester \& Katsiyannis, 2005). Thus, the knowledge, skills, and readiness of these teachers need to be enhanced so that students with special needs can be given the best guidance on self-advocacy skills. 
The guidance and counselling units in schools can help in improving the students' psychological wellbeing, personality, and discipline and providing career guidance (MOE 2012). This service is not only limited to common students but also students with special needs (Bakar \& Ishak, 2019). The guidance and counselling for students with special needs are stated in the book entitled Guidelines for Guidance and Counselling Services for Primary and Secondary Schools (MOE 2014). However, the findings from several studies showed that guidance and counselling teachers served less multicultural clients, especially students with special needs (Bali \& Othman 2017; Rasit 2014; Jaladin, 2013; Rasit 2014). They were also reluctant to provide services to students with special needs (Jaladin 2013) and lacked the knowledge on special education (Bakar \& Ahmad 2020; Rasit 2014). Teachers experienced fear and anxiety when dealing with students with special needs (Jaladin, 2013). Bakar, Aman and Abdullah(2017) stated that guidance and counselling teachers could not provide good services to students with special needs due to their workload and minimal referral of students with special needs to the unit. Instead of catering to the requirements of students with special needs, the services and programs are designed to focus on mainstream students (Salleh \& Majid 2019; Bali \& Othman 2017). Special education students are only indirectly involved in programs or activities because no specific program was executed by the guidance and counselling teachers in schools (Bali \& Othman, 2017; Rasit et al., 2012).

A study conducted by Bali and Othman (2017) revealed that guidance and counselling teachers faced challenges in providing services to students with special needs. One of the challenges was applying counselling, collaboration, and communication approaches. Applying the counselling approach was challenging because guidance and counselling teachers considered students with special needs faced with different issues. Meanwhile, the collaboration with other school staff, including those in the special education program that turned out to be a challenge. In addition, there were communication challenges for students with special needs that occurred inside or outside the school. Salleh and Majid (2019) mentioned another challenge faced by guidance and counselling teachers was implementing multicultural guidance and counselling services. There was no specific training to accommodate the counselling services to students with special needs (Saimi \& Amat, 2011). Apart from that, guidance and counselling teachers negatively perceive students with special needs that hindered the implementation of services (Bali \& Othman, 2017; Saimi and Amat, 2011). These findings are in line with a study by Toran, Muhammad, Yasin, Tahar, and Hamzah (2010), suggesting that the negative thoughts and attitudes of guidance and counselling teachers towards students with special needs that influenced their actions in providing guidance and counselling services. Hence, knowledge, skills, and readiness in implementing multicultural counselling services must be given to guidance and counselling teachers to guide students with special needs (Bali \& Othman, 2019).

It is important to study the teachers' knowledge, skills, and willingness in guiding selfadvocacy skills to students with special needs. This is because teachers will be more competent and responsible towards their duties and students' wholesome development when they have the knowledge, skills, and readiness in the teaching and guidance process. Teachers should improve their knowledge, skills, and readiness to provide better services. Hence, this study focused on teachers' knowledge, skills, and readiness in guiding self- 
advocacy skills to students with special learning needs at the secondary level. This paper focused on the following research questions:

a. Do teachers have the knowledge about the guidance of self-advocacy skills to students with special needs?

b. Do teachers have the skills to teach self-advocacy skills to students with special needs?

c. Do teachers have the readiness to teach self-advocacy skills to students with special needs?

\section{Methodology}

This case study employed a qualitative approach to explore teachers' knowledge, skills, and willingness to guide self-advocacy skills to students with special needs in secondary schools. According to Creswell (2012), qualitative research does not have a standard procedure in obtaining research data, and it focuses on obtaining the expectations and needs of all parties.

\section{Research Sites and Participants}

This study involved ten special education teachers and five guidance and counselling teachers in three schools in Gombak district, Selangor, Malaysia. The participants were purposefully selected based on predetermined criteria of having at least five years of experience teaching special education programs or serving as guidance and counselling teachers. They were willing to provide information and cooperate throughout the study. The selection of study participants was made according to Creswell's (2013) recommendation that the selected study participants must meet the study criteria and have the ability and willingness to provide information. According to Miles and Huberman (1994), qualitative study participants are small in numbers but can comprehend the context of the study in detail. Table 1 shows a summary of the participants' profile. 
DEVELOPMENT

Vol. 10, No. 3, 2021, E-ISSN: 2226-6348 @ 2021 HRMARS

Table 1. The participants' profile

\begin{tabular}{|c|c|c|c|}
\hline Background & Study participants & Number & Percentage (\%) \\
\hline \multirow[t]{2}{*}{ Teacher's Category } & $\begin{array}{l}\text { Special education } \\
\text { teachers }\end{array}$ & 10 & 67 \\
\hline & $\begin{array}{l}\text { Guidance and } \\
\text { counselling } \\
\text { teachers }\end{array}$ & 5 & 33 \\
\hline \multirow[t]{2}{*}{ Gender } & Male & 3 & 20 \\
\hline & Female & 12 & 80 \\
\hline \multirow[t]{4}{*}{ Age } & 20 to 30 years old & 2 & 13 \\
\hline & 31 to 40 years old & 6 & 40 \\
\hline & 41 to 50 years old & 5 & 34 \\
\hline & 51 to 60 years old & 2 & 13 \\
\hline Academic & Bachelor's degree & 14 & 93 \\
\hline Qualification & Master's degree & 1 & 7 \\
\hline Professional & Diploma in & 7 & 47 \\
\hline \multirow[t]{2}{*}{ Qualification } & Education & & \\
\hline & Degree (Education) & 8 & 53 \\
\hline \multirow[t]{5}{*}{ Teaching Experience } & 0 to 5 years & 0 & \\
\hline & 6 to 10 years & 7 & 47 \\
\hline & 11 to 15 years & 4 & 26 \\
\hline & 16 to 20 years & 1 & 7 \\
\hline & 21 years and above & 3 & 20 \\
\hline
\end{tabular}

Based on the information given in Table 1, fifteen study participants consisting of ten special education teachers and five guidance and counselling teachers were purposely selected in this study. The study participants consisted of twelve women and three men from various age categories that ranged from 20 to 60 years old. The majority of study participants had an academic qualification of bachelor's degree totaling up to fourteen people, while one study participant had an academic qualification of master's degree. For professional qualifications, seven study participants obtained a Diploma in Education, while eight people attained a bachelor's degree in Education. In addition, the study participants had a different duration of teaching experience in which three participants had been teaching for 5 years; four people had a teaching experience between 6 to 10 years; four participants between 11 to 15 years of teaching experience; one for the duration between 16 to 20 years; and two people who have more than 21 years of experience.

\section{Data Collection and Analysis}

In this study, an interview protocol was used to obtain the research data. The interview protocol was developed based on literature reviews. The interview data from the semistructured interviews helped the researcher acquire research information mainly on teachers' knowledge, skills, and willingness to teach self-advocacy skills to students with special needs. The data gathered were then transcribed to facilitate the data analysis. According to Merriam (2001), verbatim transcriptions are the best for data analysis. 
DEVELOPMENT

Vol. 10, No. 3, 2021, E-ISSN: 2226-6348 @ 2021 HRMARS

In the next step, the transcriptions were grouped under a predetermined theme to answer the research questions, and they were categorised according to specific subthemes and subcategories. Framework editing (Miles \& Huberman 1994) was employed where the data were given codes or themes predetermined before the in-depth data analysis. Among the themes were teachers' knowledge, skills, and readiness.

Once the data were collected, the next process was to reduce data (reduction). The data reduction process is a process that involves selecting, focusing, facilitating abstracting, and transforming data obtained from field studies (Miles, Huberman \& Saldana 2013). Data reduction is an integral part of the data analysis process. The following step was to create the data display. Data display is a process that involves the layout of data in the form of relevance or sentence continuity by categorising the data according to themes to answer the research questions. The last step was to draw conclusions and verify the data. The latter process involved the agreement between the researcher, experts, and study participants. Themes and subthemes constructed from the study data were given to experts for review and validation. The summaries, conclusions, and reports were made based on the data verified by experts. Figure 1 shows the process described above.

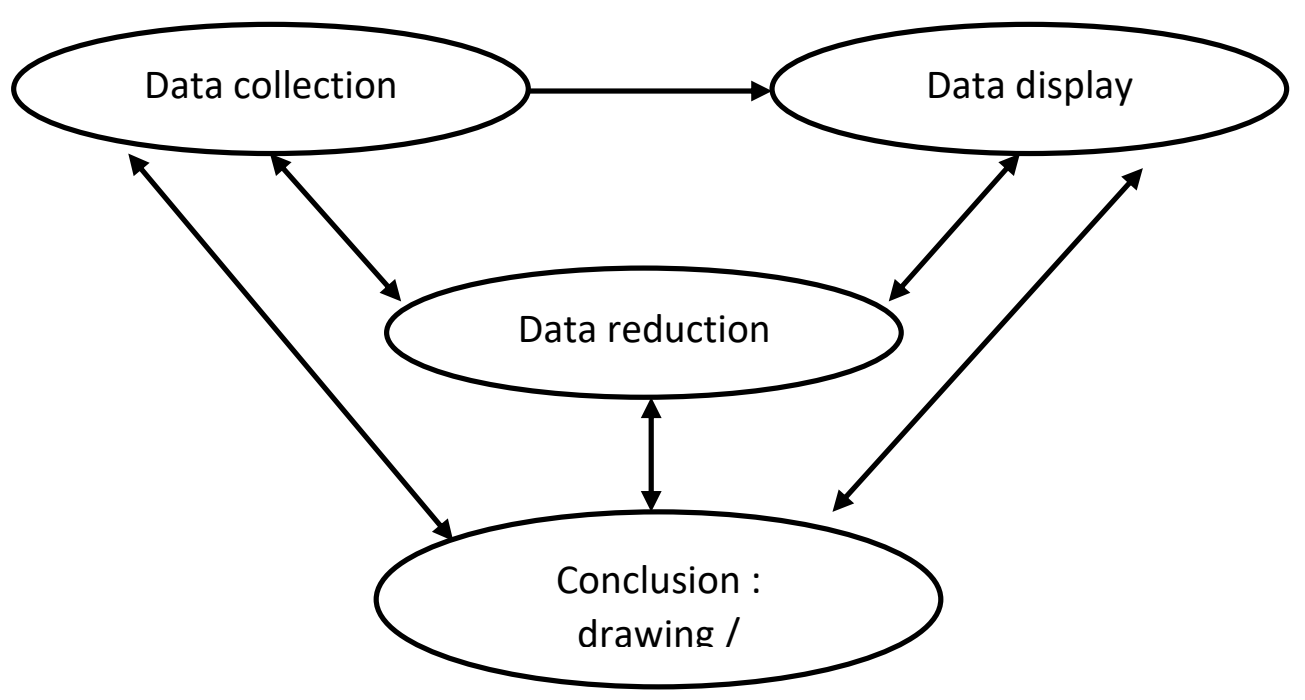

Figure 1. Framework editing adapted from Miles and Huberman (Miles and Huberman, 1994).

\section{Findings}

This section presents the study findings obtained from the semi-structured interviews conducted on fifteen study participants. The results of the study analysis were categorised into three main themes, namely teachers' knowledge, teachers' skills, and teachers' readiness to guide self-advocacy skills to students with special needs. The following is the discussion of the study findings. The next section presents the discussion of the first theme, namely teachers' knowledge.

\section{Teachers' Knowledge}

It is important to investigate teachers' knowledge, and this study explored the teachers' knowledge on self-advocacy skills. The study results found that seven study participants, 
namely GBK-K3, GPK-R1, GPK-R2, GPK-R3, GPK-R8, GBK-R9, and GBK-R10, stated they did not get any exposure to self-advocacy skills and had little understanding of the term 'selfadvocacy'. They also had no idea of the best method to teach or guide these skills. For example, GBK-K3 said:

Honestly, I didn't get any specific exposure to it. I know l've been exposed to the matters of self-introduction and related rights, but when it comes to selfadvocacy, this is the first time hearing it. The term itself is new for me.

Likewise, GPK-R1 stated:

I wasn't given the exposure regarding self-advocacy; my teaching is only based on my experience. When given the timetable, having to teach self-management subject, I just follow through. I use the textbook. It was even worse back then when we didn't have a textbook; we have to find our own resources.

GPK-R2, GPK-R3, and GPK-R8 were also on the same page, stating the following:

There wasn't any direct exposure at all, mostly depending on my own personal experience.(GPK - R2)

As far as I'm concerned, there wasn't any exposure regarding the teaching of selfadvocacy skills. I only use textbook as guidance accordingly.(GPK - R3)

I'm certain that I was never exposed to these skills of self-advocacy.(GPK - R8)

Based on the interview data, the study participants did not receive any exposure to selfadvocacy skills, either directly or indirectly. The teaching was based only on the textbook and personal experience.

\section{Teachers' Skills}

Apart from teachers' knowledge, this study also ventured into the abilities possessed by teachers to teach self-advocacy skills to students with special needs. The study findings revealed that participants lacked experience in teaching self-advocacy skills to students with special needs. This result will further be substantiated through the following findings.

Participant GPK-R9 expressed his inexperience in dealing with students with special needs as he majored in teaching mainstream students. Thus, he asserted that exposure to courses and training should be given to teachers who are new to the field:

Personally, as a mainstream teacher, adapting to teaching students with special needs is difficult. I need more professional help in dealing with them. Courses and workshops would be a huge help for me to understand my students.

GPK participants also expressed their difficulties teaching self-advocacy skills to their students with special needs due to their lack of experience. This statement was mentioned by GBK-K1 as follows:

Frankly, it is tough for me to understand my students. I don't want this to hinder my passion in teaching. So, I believe that by trying to understand and learn more about my students, I would be able to love my job better. 
All participants lacked experience in teaching self-advocacy skills. In addition, some of them had very minimal experience in teaching students with special needs.

\section{Teachers' Readiness}

Teachers' readiness in teaching self advocacy skill is an important aspect apart from their knowledge and skills. According to Jusoh (2012), the effectiveness of teaching students with special needs is fully dependent on teachers' readiness, especially in terms of attitude and knowledge level in using teaching strategies and approaches suitable to students' needs. From the data collection there were three main subthemes from the interviews on the participants, namely: 1) teachers require extensive training courses and workshops, 2) teachers are keen to teach self-advocacy skills, and 3) the need for exposure to teachers. The discussions are as follows.

a. Teachers require extensive training courses and workshops

Most teachers were eager to teach self-advocacy skills to their students. However, they needed extensive training and workshops to help them to do so effectively. Four participants, namely GBK-K5, GBK-K4, GPK-R7, and GPK-R1. They suggested that extensive training and workshops on self-advocacy skills should be offered to them. According to GBK-K5, selfadvocacy skills are relatively new; hence, they need support to teach the skills. The participant mentioned this statement:

I need supports and guidance as everything is new to me.

GPK-R4 noted that extensive training courses and workshops will be a tremendous help for him to teach self-advocacy skills correctly to students. GBK-K4 mentioned:

If there is such courses or workshops, I can learn to use the best and proper methodologies.

In addition, he was also interested in joining courses or workshops to know his students better. GBK-K4 stated:

I think there is a need to have courses and workshops to help me understand my student with special needs better. Often than not, when I am in class, I find it difficult to break the barriers between us.

According to GPK-R7, training and workshops arise because most teachers lacked the relevant skills to motivate their students intrinsically. GPK-R7 mentioned:

I think we are well equipped to teach the students with special needs extrinsically; however, we are clueless on how to motivate, thus develop them intrinsically.

On the same note, GPK-R8 shared a similar opinion. He believed that self-advocacy skills courses and workshops should be introduced to teachers so that the knowledge can be extended to their students. GPK-R8 mentioned:

I want a workshop or courses that I can attend that will help me to learn how to teach self-advocacy skills to my students. 
In general, teachers require suitable training and workshops on teaching self-advocacy skills. Teachers will learn and understand different methods and approaches to teach relevant selfadvocacy skills to their students with special needs through training and workshops.

b. Interest in teaching self-advocacy skills

The study findings found that all fifteen participants were interested in teaching self-advocacy skills to their students with special needs. In addition, all participants have the same sentiment that it is a privilege to teach self-advocacy skills because not everyone can teach the skills to students with special needs. GBK-K3 said:

If the opportunity comes, I would love to teach self-advocacy skills to my students, as not everyone understands them. They have a special place in my heart, so I don't see the problem in trying.

One participant was interested in teaching the skills because he fell in love with teaching and understanding students with special needs after participating in a special education course organised by the Ministry of Education. GBK-K4 mentioned this statement:

I am indeed interested. When I went through the special needs student workshop the other day. I felt like I can do more to help and understand them. It changed me. After the course, I spent more time in learning about them. I am extremely interested to learn more about how I can help them.

However, GBK-K4 shared a different view. He linked his interest to teach self-advocacy skills to his eagerness to learn about appropriate approaches to teach the skills. GBK-K4 mentioned:

Well, true I want to learn more. Maybe I'll be able to teach the skills better after this. I am aware of the skills; however, I am not quite sure on how to teach the skills to my students.

In addition, GPK-R8 was also interested in teaching self-advocacy skills across the curriculum. She stated:

I am interested to teach these skills across the curriculum. I feel like it is interesting to try it out.

In conclusion, the finding suggested demand for training courses and workshops on selfadvocacy skills for teachers. The participants were interested in teaching the skills and willing to use appropriate teaching modules. In addition, teachers were also eager to teach selfadvocacy skills to students with special needs.

c. Experience disclosure to teachers

Experience disclosure is important in introducing something new to individuals. From experiences, teachers learned how to guide their special needs students appropriately. This finding revealed that the participants have issues in providing their best service to students. However, these issues limited their experiences in guiding and teaching their students. For example, GBK-K2 talked about the time limitation with students with special needs. His time 
in school is divided between many trivial tasks, which limited his time with his students with special needs. He mentioned:

I spend more time managing the mainstream students and left with little to no time to help my students with special needs.

The issue resonates well with GBK-K1. He admitted that he is more focused on mainstream students and feels pressured to be involved with students with special needs. He mentioned:

Frankly speaking, it's hard for me to teach students with special needs. I don't really know or understand them. I feel pressured to not only teach but to learn to teach them on the same time.

The participant was more interested in teaching mainstream students compared to students with special needs. As a result, he is often pressured when asked to teach the latter. In contrast, a participant participated in an introductory course to special education by the Ministry of Education and shared a different view. He is more open to the idea of providing counselling to students with special needs. In addition, he conducted action research with the Ministry of Education to understand students with special needs better. GBK-K4 stated:

After going through the introductory course, I became more interested to know more about student with special needs. They are special. I spent more time with them after the course. I am interested to learn and know more about them.

GBK-K5 agreed and mentioned:

I am more comfortable dealing with students with special needs after I went through the course and finished my action research. The kids have opened up to me and would occasionally greet and share their problems with me.

From the findings, participants required experience disclosure with students with special needs before teaching them. The experience will tackle their fears in dealing with the students. Overall, the study found that all participants were eager to teach self-advocacy skills to students with special needs. However, they need help in courses and workshops to expose them to the students' needs. In addition, the participants were also interested in teaching self-advocacy skills to their students. Some were eager to go through courses to help them to do so. However, the participants needed more experience disclosure with students with special needs. It is proven that experienced teachers are more opened to help these students.

\section{Discussion}

Besides content and pedagogical knowledge, teachers' classroom management, interpersonal skills, and readiness to adapt are the key factors in ensuring an effective teaching and learning session. According to Derapa and Mohamed (2019), skills and knowledge are the key elements in ensuring the effectiveness of teaching any skills. This statement is parallel with the results of this study. This study found that almost all participants lacked the basic skills to teach self-advocacy skills to students with special needs. This statement is supported by the data from the interviews, whereby all participants were not 
formally exposed to the teaching of self-advocacy skills before the study. However, they are aware of the skills based on their personal readings and experiences. This finding is parallel with a study by Lan (2017); Michale and Zidan (2018). In this study, the teacher trainees did not receive any formal training or exposure on the importance of self-advocacy skills for students with special needs. Therefore, teachers are facing difficulties to teach self-advocacy skills without any proper guideline or resources. Tahir, Mustafa, and Yasin (2009) believe that teachers require training to teach students with special needs. Therefore, training and exposures to self-advocacy skills should be provided by relevant parties to special needs teachers. The challenges and obstacles in teaching self-advocacy skills can be removed if the teachers are exposed to them beforehand (Bali \& Othman, 2019).

Most participants lacked the skills to teach self-advocacy skills to students with special needs. This finding is similar to the studies by Lan (2007); Betinez et al (2009). Even after almost a decade has passed, teachers are not skilled and trained to teach self-advocacy skills to students with special needs. According to Tahir et al. (2009), teachers who have an in-depth understanding of their subject matters are most likely to motivate students with special needs during lessons. This statement is in line with another study by Salleh et al. (2012) that highly skilled teachers would provide an effective lesson to their students with special needs. Therefore, the special education teachers' teaching skills regarding self-advocacy skills should be strengthened.

Teachers' readiness to adapt and teach is pivotal to create effective lessons. This study found that almost all participants were ready and eager to teach self-advocacy skills. However, they require special training through courses or workshops on self-advocacy skills. Through the courses and workshops, the teachers can learn about the approaches and methods to teach self-advocacy skills to students with special needs. This statement is in line with Derapa and Mohamed's (2009) finding that attending relevant courses or workshops can improve teachers' teachings in the classroom. Thus, special training courses and workshops should be introduced on self-advocacy skills. Furthermore, special training should be given to counsellors to encourage them to conduct counselling sessions for students with special needs (Saimi \& Amat, 2011). In addition, the participants were also keen to teach selfadvocacy skills to their respective students. They were also interested in using modules that are constructed for that purpose. This statement is in line with Xin, Accardo, Shuff, Cormier and Doorman's (2006) suggestion that teachers require global education. Through global education, teachers will be exposed and trained with various skills and training to teach students with special needs. Teachers need to attend courses and workshops to teach selfadvocacy skills. Besides that, special education teachers faced difficulties conducting counselling sessions with their respective students (Salleh \& Majid, 2019; Saimi \& Amat, 2011).

This study also found that the participants have limitations when dealing with students with special needs. Consequently, the limitations hindered their interactions with their special needs students. Some participants are burdened with school's tasks and responsibilities involving mainstream students. They spent little to no time dealing with students with special needs. Some of them are pressured when asked to deal with students with special needs. This is a concern because they failed to follow the principles in the guideline provided to 
counsellors by the Ministry of Education. The guideline stated that their job scopes are inclusive of mainstream and students with special needs. The job scopes can be found on page 18 for principles 18 and 19 on students with special needs. In addition, the basic principles of counselling mention that counselling should be inclusively accessible to all students. The first until the fifth principles mentioned that counselling should be accessible to every student so they would be able to learn about positive social conducts generally. Thus, the teachers' duties are for every student in the school.

Real-life experience in guiding students with special needs should be provided to teachers to learn about their students. Through this experience disclosure, negative stigmas towards students with special needs can be minimised. Besides that, the negligence towards helping and providing guidance to students with special needs can be minimised if teachers are given the experience to deal with them (Bali \& Othman, 2017; Saimi \& Amat, 2011). This is because stereotypes and prejudice against students with special needs can influence teachers' treatment towards them when providing counselling services. (Toran et al. 2010). Therefore, teachers must be provided with supports and training to learn about self-advocacy skills. In addition, teachers should prepare themselves mentally to provide the best services to students with special needs regardless of their backgrounds (Bakar et al., 2017).

\section{Conclusion}

In general, almost all participants did not have the skills and knowledge to teach self-advocacy skills to students with special needs. However, they are keen and interested to attend professional training to learn how to teach the skills to their students. In addition, real-life experience in dealing with students with special needs should be provided, especially to teachers without any counselling background. In providing more training to the teachers, suitable courses and workshops should be handled by relevant parties to strengthen the teachers' understanding of self-advocacy skills. The teachers should also work together with class teachers in finding the best approaches to help students with special needs. Through these collaborative efforts, no students will be left out.

This study proposes courses and workshops on self-advocacy skills for teachers in the Malaysian education system. Modules for the proposed courses and workshops should be developed by relevant parties such as the district's and state's educational offices or the Ministry of Education. In addition, the collaboration between school counsellors and special education teachers should be encouraged to help students. The introductory courses on special needs education should be continued and improvised to help teachers without special education background. This paper also suggests that further studies should focus on teachers' content knowledge, skills, and readiness to teach self-advocacy skills.

\section{Acknowledgement}

We thank PP-FPEND-2021 for the support. The first author grateful thank is extended to the Ministry of Education for the scholarship awarded for pursing doctoral degree and sincere gratitude is hereby extended to Assoc., Prof Dr. Manisah Mohd Ali and Dr. Norshidah Mohamad Salleh, as supervisors, both of whom have unceasingly helped in the completion of this paper. 
DEVELOPMENT

Vol. 10, No. 3, 2021, E-ISSN: 2226-6348 @ 2021 HRMARS

\section{Corresponding Author}

Prof. Madya Dr. Manisah Mohd Ali

National University of Malaysia, Malaysia, Centre Of Education and Community Wellbeing, Faculty of Education, National University of Malaysia, 43600 Bangi, Selangor.

Email:mma@ukm.edu.my

\section{References}

Ahmad, N. A., \& Hanifah, N. A. (2015) Tahap pengetahuan guru pendidikan khas apabila mengurus tingkah laku murid bermasalah pembelajaran (special education teacher's level of knowledge in dealing with learning disabilities student. Asia Pacific Journal of Educators and Education, Vol. 30, 73-88.

Azman, F. A., Amat, S., Hashim, K., \& Ai, T. Y. (2019) Pendekatan psikopendidikan terhadap program pendidikan khas integrasi (PPKI). Southeast Asia Psychology Journal, 8, 116 129.

Bakar, A. Y. A., \& Ishak, N. M. (2019) Kaunseling dalam pendidikan pintar dan berbakat di Malaysia, Edisi ke-2, Bangi: Penerbit UKM.

Bakar, A. Y. A., \& Ahmad, S. N. (2020) Counselling and Guidance Services for Special Education Pupils: An Analysis of Research Literatures. International Conference on Special Education In South East Asia Region 10th Series 2020. Social Sciences Education and Humanities (GCSSSEH) 4

Bakar, R. A., Aman, R. C., \& Abdullah, S. M. S. (2017) Efikasi kendiri, sikap, kesediaan dan cabaran menjalankan kaunseling klien berkeperluan khas. Journal Of Nusantara Studies, $2(2), 264-281$.

Bali, N., \& Othman, M. H. (2017) Keterlibatan dan cabaran guru bimbingan dan kaunseling sekolah terhadap murid berkeperluan khas. Asian Social Work Journal (ASWJ), 2 (2),110.

Bali, N., \& Othman, M. H. (2019) Pelaksanaan aktiviti bimbingan dan kaunseling kepada murid berkeperluan khas. Asian Pacific Journal of Educators and Education, 34, 87 - 103.

Benitez, D., Morningstar, M. E., \& Frey, B. (2009) A multistate survey of special education teachers' perceptions of their transition competencies. Career Development for Exceptional Individuals, 32, 6-16.

Chhabra, S., Srivastava, R., \& Srivastava, I. (2010). Inclusive education in Botswana: The perceptions of school teachers. Journal of Disability Policy Studies, 20(4), 219-228.

Derapa, N. F., \& Mohamed, S. (2019). Kesedian guru pendidikan khas dalam melaksanakan mata pelajaran asas tanaman. Jurnal Optodepadegogi, 4 (1), $66-71$.

He, Y., Lundgren, K., \& Pynes, P. (2017) Impact of short-term study abroad program: Inservice teachers' development of intercultural competence and pedagogical beliefs. Teaching and Teacher Education, 66(2017), 147-15.

Jaladin, R. A. M. (2013). Barrier and challengers in the practice of multicultural counselling in Malaysia: A qualitative interview study. Counselling Psychology Quarterly, 26(2), 174 189.

Jusoh, R. (2012) Effects of teachers' readiness in teaching and learning of entrepreneurship education in primary schools. International Interdisciplinary Journal of Education, 1, 98102.

Lamont, A. E., Markle, R. S., Wright, A., Abraczinskas, M., Siddall, J., Wandersman, A., Imm, P., \& Cook, B. (2018) Innovative methods in evaluation: An application of latent class 
analysis to assess how teachers adopt educational innovations. American Journal of Evaluation, 39(3), 364-382.

Lan, Y. S. (2007). Self-advocacy movement of person with learning disabilities: A case study in the Malaysia context. Tesis Master, Fakulti Pendidikan. Universiti Malaya.

Landmark, L. J., Ju, S., \& Zhang, D. (2010) Substantained Best Practices in Transition: Fifteen Plus Years Later. Career Develepment and Transition For. Exceptional Individuals, 35, $143-154$.

Leko, M. M., Brownell, M. T., Sindelar, P. T., \& Kiely, M. T. (2015) Envisioning the future of special education personnel preparation in a standards-based era. Exceptional Children, 82(1), 25-43.

Mazzotti, V. L., Rowe, D. A., Simonsen, M. L., Boaz, B., \& VanAvery, C. (2018) Steps for implementing a state-level professional development plan for secondary transition. Career Development and Transition for Exceptional Individuals, 41(1), 56-62.

Michale, R., \& Zidan, H. M. (2018) Differences in self-advocacy among hard of hearing and typical hearing students. Research in Development Disabilities, 72, 118 - 127.

Miles, M. B., \& Huberman, A. M. (1994) Qualitative data analysis : An ecpanded sourcebook (2nd ed.) London : Sage Publication.

Miles, M. B., Huberman, A.M., \& Saldana, J. (2013) Qualitative data analysis: A method sourcebook. SAGE publication, Incorporated.

Nor, S. M., \& Rashed, Z. N. (2018). Peranan dan cabaran guru-guru pendidikan khas membentuk kemenjadian murid-murid masalah pendengaran dalam abad ke 21 . Journal of Quran Sunnah Education and Special Needs, I (1).

Ok, M. W., Hughes, J. E., \& Boklage, A. (2017) Teaching and learning biology with iPads for high school students with disabilities. Journal of Educational Computing Research, 56(6), 911-939.

Rashid, Z. A. (2016). Tahap kesediaan dalam aspek pengetahuan dan keperluan latihan berfokuskan aplikasi KBAT. Laporan projek ljazah Sarjana Pendidikan Teknikal. Fakulti Pendidikan Teknikal dan Vokasional. Universiti Tun Hussein Onn. http://eprints.uthm.edu.my/id/eprint/9086/1/Zarina_Abdul_Rashid.pdf.

Rasit, H. H. (2014). Perkhidmatan bimbingan dan kaunseling kepada pelajar bermasalah di Program Pendidikan Khas Integrasi. Tesis PhD yang tidak diterbitkan. Bangi : Universiti Kebangsaan Malaysia.

Rasit, H. H., Toran, H., \& Amat, S. (2012) Implementation of guidance and counselling service to students with special needs in Selangor. Journal of Special Education, 2, 76 - 87.

Saimi, A. (2018) Program transisi kerjaya untuk murid berkeperluan khas sebagai persediaan ke alam kerjaya. Jurnal Pendidikan Guru.

Saimi, A., \& Amat, S. (2011) Kesediaan dan keperluan latihan kepada kaunselor sekolah dalam program pendidikan khas. Journal of Special Education, 1 (1), 129 - 141.

Salleh, N. M., Alias, A., \& Jelas, Z. M. (2009). Sejarah Pendidikan Khas di Malaysia. DIm Zalizan Mohd Jelas (pny.). Pendidikan KanakKanak Berkeperluan Khas: Konsep dan Amalan, hlm. 1 - 14. Bangi: Fakulti Pendidikan UKM.

Salleh, S. M., \& Majid, R. A. (2019) Persepsi guru bimbingan dan kaunseling dalam menjalankan kaunseling kerjaya dikalangan murid berkeperluan khas. E-prosiding Persidangan Antarabangsa Sains Sosial dan Kemanusiaan.

Tahir, L. M., Mustafa, N. Q., \& Yasin, M. H. M. (2009) Pendidikan teknik dan vokasional untuk pelajar berkeperluan khas. Jurnal Pendidik dan Pendidikan, 24, 73 - 78. 
Toran, H., Muhammad, T. A., Yasin, M. H. M., Tahar, M. M., \& Hamzah, N. H. (2010). Pengetahuan dan sikap rakan sebaya terhadap pelajar kurang upaya di sebuah IPTA di Malaysia. Asian Journal of Teaching and Learning in Hinger Education, 2 (2), 22 - 34.

Xin, J. F., Accardo, A. L., Shuff, M., Cormier, M., \& Doorman, D. (2016). Integrating global content into special education teacher preparation programs. Teacher Education and Special Education, 39(3), 165-175.

Zainal, M. S., \& Hashim, H. (2019) The implimentation of transition programme for students with learning disabilities in Malaysia. Creative Education, 10, 1802 - 1812.

Zhang, D., Ivester, J., \& Katsiyannis, A. (2005) Teacher's view of transition services result from state wide survey in South Carolina. Education and Trainning in Developmental Disabilitie, . 40, 360 - 367. 